\title{
Alpha- and beta- adrenergic receptors regulate inflammatory responses to acute and chronic sleep fragmentation in mice
}

\author{
Nicholas Wheeler ${ }^{1,2}$, David Ensminger ${ }^{3}$, Megan Rowe $^{1}$, Zachary Wriedt $^{1}$, Noah Ashley ${ }^{\text {Corresp. } 1}$ \\ 1 Department of Biology, Western Kentucky University, Bowling Green, Kentucky, United States \\ 2 College of Veterinary Medicine, Mississippi State University, Starkville, Mississippi, United States \\ 3 Department of Integrative Biology, University of California, Berkeley, Berkeley, California, United States \\ Corresponding Author: Noah Ashley \\ Email address: noah.ashley@wku.edu
}

Sleep is a recuperative process, and its dysregulation has cognitive, metabolic, and immunological effects that are largely deleterious to human health. Epidemiological and empirical studies have suggested that sleep fragmentation (SF) as result of obstructive sleep apnea (OSA) and other sleep abnormalities leads to pronounced inflammatory responses, which are influenced by the sympathetic nervous system (SNS). However, the underlying molecular mechanisms contributing to SNS regulation of SF-induced inflammation are not fully understood. To assess the effects of the SNS upon inflammatory responses to SF, C57BL/6j female mice were placed in automated SF chambers with horizontally moving bars across the bottom of each cage at specified intervals to disrupt sleep. Mice were first subjected to either control (no bar movement), acute sleep fragmentation (ASF), or chronic sleep fragmentation (CSF) on a 12:12-h light/dark schedule. ASF involved a bar sweep every $120 \mathrm{sec}$ for $24 \mathrm{~h}$, whereas CSF involved a bar sweep every $120 \mathrm{sec}$ for $12 \mathrm{~h}$ (during $12 \mathrm{~L}$; resting period) over a period of 4 weeks. After exposure to these conditions, mice received an intraperitoneal injection of either phentolamine ( $5 \mathrm{mg} / \mathrm{kg} \mathrm{BW}$; an $\alpha$-adrenergic receptor blocker), propranolol ( $5 \mathrm{mg} / \mathrm{kg} \mathrm{BW}$; a $\beta$-adrenergic receptor blocker), or vehicle (saline). Serum corticosterone concentration, brain and peripheral cytokine (IL1 $\beta$, TNF $\alpha$, and TGF $\beta$ ) mRNA expression, and body mass were assessed. ASF and CSF significantly elevated serum corticosterone concentrations as well as cytokine mRNA expression levels compared with controls, and mice subjected to CSF had decreased body mass relative to controls. Mice subjected to CSF and treated with phentolamine or propranolol had a greater propensity for a decrease in cytokine gene expression compared with ASF, but effects were tissue-specific. Taken together, these results suggest that both $\alpha$ - and $\beta$-adrenergic receptors contribute to the SNS mediation of inflammatory responses, and adrenergic antagonists may effectively mitigate tissuespecific SF-mediated inflammation.

Peer] reviewing PDF | (2020:12:55981:1:1:NEW 12 May 2021) 


\section{Alpha- and beta- adrenergic receptors regulate}

\section{3 inflammatory responses to acute and chronic sleep}

\section{4 fragmentation in mice}

7 Nicholas D. Wheeler ${ }^{1,2}$ (0000-0002-7974-2909), David C. Ensminger ${ }^{1,3}$ (0000-0001-5554-1638),

8 Megan M. Rowe ${ }^{1}$, Zachary S. Wreidt ${ }^{1}$, Noah T. Ashley ${ }^{1}(0000-0002-9850-0681)$

9

$10 \quad{ }^{1}$ Department of Biology, Western Kentucky University, Bowling Green, KY 42101

$11{ }^{2}$ College of Veterinary Medicine, Mississippi State University, Starkville, MS 39762

$12{ }^{3}$ Department of Integrative Biology, University of California, Valley Life Sciences Building,

13 Berkeley, CA 94720

14

15 Corresponding Author:

16 Noah T. Ashley ${ }^{1}$ Department of Biology, Western Kentucky University, Bowling Green,

17 Kentucky, KY

18 Email address: noah.ashley@wku.edu 


\section{Abstract}

Sleep is a recuperative process, and its dysregulation has cognitive, metabolic, and

22 immunological effects that are largely deleterious to human health. Epidemiological and empirical studies have suggested that sleep fragmentation (SF) as result of obstructive sleep apnea (OSA) and other sleep abnormalities leads to pronounced inflammatory responses, which are influenced by the sympathetic nervous system (SNS). However, the underlying molecular mechanisms contributing to SNS regulation of SF-induced inflammation are not fully understood. To assess the effects of the SNS upon inflammatory responses to SF, C57BL/6j female mice were placed in automated SF chambers with horizontally moving bars across the bottom of each cage at specified intervals to disrupt sleep. Mice were first subjected to either control (no bar movement), acute sleep fragmentation (ASF), or chronic sleep fragmentation (CSF) on a 12:12-h light/dark schedule. ASF involved a bar sweep every $120 \mathrm{sec}$ for $24 \mathrm{~h}$, whereas CSF involved a bar sweep every $120 \mathrm{sec}$ for $12 \mathrm{~h}$ (during $12 \mathrm{~L}$; resting period) over a period of 4 weeks. After exposure to these conditions, mice received an intraperitoneal injection of either phentolamine ( $5 \mathrm{mg} / \mathrm{kg} \mathrm{BW}$; an $\alpha$-adrenergic receptor blocker), propranolol (5mg/kg BW; a $\beta$-adrenergic receptor blocker), or vehicle (saline). Serum corticosterone concentration, brain and peripheral cytokine (IL1 $\beta, T N F \alpha$, and TGF $\beta$ ) mRNA expression, and body mass were assessed. ASF and CSF significantly elevated serum corticosterone concentrations as well as cytokine mRNA expression levels compared with controls, and mice subjected to CSF had decreased body mass relative to controls. Mice subjected to CSF and treated with phentolamine or propranolol had a greater propensity for a decrease in cytokine gene expression compared

41 with ASF, but effects were tissue-specific. Taken together, these results suggest that both $\alpha$ - and 
$42 \beta$-adrenergic receptors contribute to the SNS mediation of inflammatory responses, and

43 adrenergic antagonists may effectively mitigate tissue-specific SF-mediated inflammation.

44

45 Introduction

46

47

48

49

50

51

52

53

54

55

56

57

58

59

60

61

62

63

64

Sleep is restorative, and its dysregulation can have lead to cognitive, metabolic, and immunological consequences that can have deleterious effects upon human health. Obstructive sleep apnea (OSA) is characterized by repeated episodes of airway obstruction, intermittent oxygen saturation, and sleep disruption, and this condition had become more prevalent due to the obesity epidemic (Peppard et al., 2000; Young et al., 2002). It is well known that OSA, as well as sleep disruptions in general, lead to inflammatory responses in the brain and periphery (Frey et al., 2007; Wisor et al., 2011). Dysregulated sleep and OSA are associated with increased circulating concentrations of proinflammatory cytokines, including interleukin (IL)-1, IL-6, and tumor necrosis factor (TNF)- $\alpha$ (Faraut et al., 2012), which are important molecular signatures of a pro-inflammatory response (Ashley et al., 2012). The progressive build-up of inflammatory insults can promote a systemic chronic inflammatory state that can lead to cardiovascular and metabolic disease, as well as cancer and neurogenerative disorders (Straub and Schradin, 2016; Furman et al., 2019)

It is well known that hormonal responses regulate inflammatory responses (Silervman and Sternberg, 2012; Cain and Cidlowski, 2017); however, there are few empirical studies investigating these responses within the context of sleep loss (see Mishra et. al., 2020). The activation of the hypothalamic-pituitary-adrenal (HPA) axis and sympathetic nervous system (SNS) are commonly identified as physiological stress responses (Suchecki et al., 1998; Meerlo et al., 2008), and can be triggered by sleep restriction or deprivation. Sleep curtailment can 
65 increase SNS activity and subsequently an elevation of norepinephrine (NE) released through

66 noradrenergic neurons and epinephrine and NE from the adrenal medullae (Dismdale et al.,

67 1995; Tiemeier et al., 2002; Mishra et al., 2020). Glucocorticoids are released from adrenal

68 cortices via HPA activation (Suchecki et al., 1998; Meerlo et al., 2008) several minutes after

69 SNS stimulation. While effects of acute sleep loss on SNS and HPA activity can be considered

70 mild or adaptive, chronic sleep loss caused by OSA, shift work, and modern lifestyles can

71 contribute to more deleterious effects such as cardiovascular and metabolic disease, obesity and

72 neurological disorders (Schwartz et al., 1999; Mavanji et al., 2012; Zielinksi et al., 2013). Our

73 laboratory previously showed that SF-induced increases in cytokine gene expression and serum

74 proteins were mitigated by chemical sympathectomy, confirming that inhibition of the SNS

75 reduces inflammatory responses from acute and chronic SF (Mishra et al., 2020). However, it is

76 unknown how NE is acting on these target tissues to regulate inflammation.

77 The aim of this study was to assess the role of $\alpha$ - and $\beta$-adrenergic receptors in

78 modulating inflammatory responses to acute and chronic SF. To test the effect of the SNS on

79 inflammatory responses to SF, female C57BL/6 mice were subjected to ASF, CSF, or control

80 (CON) conditions and injected with either an $\alpha$-adrenergic receptor antagonist, phentolamine

$81(5 \mathrm{mg} / \mathrm{kg} \mathrm{BW})$, a $\beta$-adrenergic receptor antagonist, propranolol (5mg/kg BW), or vehicle (saline).

82 Propranolol is a non-selective competitive $\beta$-adrenergic receptor antagonist that also crosses the

83 blood-brain barrier. It blocks the action of catecholamines from binding to both $\beta_{1}$ and $\beta_{2}$

84 adrenergic receptors. Phentolamine is a non-selective $\alpha$-adrenergic receptor antagonist that has

85 been commonly used to treat hypertension by acting on blood vessels to induce dilation. It

86 competitively blocks both $\alpha-1$ and $\alpha-2$ receptors and can cross the blood-brain-barrier (Richards,

87 1978; Auer, 1981; Limberger et al., 1989; Antunes-Rodrigues et al. 1993). Alpha-1 receptors are 
88 typically found in vascular smooth muscle while $\alpha-2$ receptors are detected in the brain and 89 periphery and are thought to modulate sympathetic outflow in the brainstem (Reid 1986). Brain

90 and peripheral tissues will be assessed for cytokine gene expression, specifically the

91 hypothalamus, hippocampus, and prefrontal cortex (for brain) and spleen, white adipose tissue,

92 liver, and heart (for periphery). These regions were selected based upon past studies that have

93 reported an inflammatory response in those specific tissues from sleep fragmentation (Dumaine 94 and Ashley, 2015; Mishra et al., 2020).

Sleep loss stimulates nerve fibers from the SNS to release the neurotransmitter norepinephrine and bind to leukocyte adrenergic receptors (Irwin and Opp, 2017), which leads to expression of pro-inflammatory cytokines. In the immune system, myeloid cells typically express $\alpha$ - and $\beta$-adrenergic receptors, whereas lymphocytes largely express $\beta$-adrenergic receptors (Fuchs et al., 1988). As the majority of immune cells in the periphery predominantly express $\beta$-adrenergic receptors (Liu and Hong, 2003; Kolmus, 2015), we hypothesized that $\beta$ adrenergic receptor blockade would reduce SF-induced inflammatory responses more than $\alpha$ adrenergic receptor blockade.

\section{Materials \& Methods}

\section{Animals}

The mice used for this study were bred from the mouse colony housed in the mouse colony room at Western Kentucky University. Female C57BL/6j mice $(n=120)$ were housed in our colony room $\left(12: 12\right.$-h light-dark cycle, lights on at $\left.0800,21^{\circ} \mathrm{C} \pm 1{ }^{\circ} \mathrm{C}\right)$ at Western Kentucky University. After weaning at 21 days of age, female mice were separated into polypropylene cages with same-sex littermates and provided with corncob bedding, and food and water ad 
111 libitum. Female mice were used in consideration of the NIH Notice Number: NOT-OD-15-102,

112 which highlights the over-reliance on male animals and cells in basic and clinical research and

113 requests for more studies to consider using female organisms. Female mice $>8$ weeks of age

114 were selected for experiments and placed in automated sleep fragmentation chambers with

115 chambers housing no more than 5 mice (Lafayette Instrument Company; Lafayette, IN; model

116 80390). Each cage was provided corncob bedding, and food as well as water were ad libitum.

117 Mice were tagged with numbered ear tags and then acclimated to the automated sleep

118 fragmentation chamber for 72 hours prior to initiating SF experiments. Mice were used as a

119 model for this study due to their anatomical, physiological, and genetic similarity to humans.

120 This study was conducted under the approval of the Institutional Animal Care and Use

121 Committee at Western Kentucky University (\#19-14), and the procedures followed the National

122 Institutes of Health's "Guide for the Use and Care of Laboratory Animals" and international

123 ethics standards. Mice were to be euthanized if injured by the sleep fragmentation apparatus or in

124 physiological distress, however, this was not necessary.

125

126 Experiment 1: Acute Sleep Fragmentation (ASF)

127 Sample sizes were aimed at having at least 6 mice per group and groups were randomized

128 by weight. The order of treatments and location of mouse cages were randomly designated and

129 was only aware to the first author. Fifty-three mice received the following pharmacological

130 treatments at 07:30 (30 min before lights on) using a single intraperitoneal injection: 18 mice

131 were treated with phentolamine $(5.0 \mathrm{mg} / \mathrm{kg} \mathrm{BW}$; an $\alpha$-adrenergic receptor blocker $), 18$ mice were

132 treated with propranolol (5.0 mg/kg BW; a $\beta$-adrenergic receptor blocker), and 17 mice were

133 treated with vehicle $(0.9 \% \mathrm{NaCl}$ solution $)$. Dosages of phentolamine and propranolol were based 
134 upon previous studies that effectively inhibited signaling of the sympathetic nervous system

135 while under varying types of stressful stimuli (Allison et al. 1969, Hermansen and Hyttel 1971,

136 Fabian et al. 1973, Hall et al. 1987, Sim et al. 2012, Jun et al. 2014). Thirty minutes following

137 injections ( $08: 00$, lights on), experimental mice ( $n=27 ; n=9$ injected with phentolamine, $n=9$

138 injected with propranolol, and $n=9$ injected with vehicle) were subjected to ASF; i.e. the

139 sweeping bar set to move horizontally at an interval of 120 seconds for 24 hours. This rate is

140 comparable to sleep disruptions that occur in humans with severe sleep apnea (Ramesh 2009,

141 Goyal and Johnson 2017). The remaining mice $(n=26 ; n=9$ injected with phentolamine, $n=9$

142 injected with propranolol, and $n=8$ injected with vehicle) were not subjected to any bar sweeps

143 (controls), but were still housed in the SF chamber.

Experiment 2: Chronic Sleep Fragmentation (CSF)

Sample sizes were aimed at having at least 6 mice per group and groups were randomized

147 by weight. The order of treatments and location of mouse cages were randomly designated, and

148 was only aware to the first author. To induce CSF, experimental mice $(n=30)$ were subjected to

149 a horizontal sweeping bar that moved every $120 \mathrm{~s} \mathrm{(30} \mathrm{swipes/h)} \mathrm{during} \mathrm{the} \mathrm{light} \mathrm{phase} \mathrm{(from}$

150 8:00 to 20:00) every day for 4 weeks (28 days), while the control mice $(n=30)$ were not

151 subjected to any bar sweeps. On the $27^{\text {th }}$ day of CSF, 24 hours prior to tissue collection,

152 experimental mice $(n=30 ; n=10$ injected with phentolamine, $n=10$ injected with propranolol,

153 and $n=10$ injected with vehicle) and control mice ( $n=30 ; n=10$ injected with phentolamine, $n$

$154=10$ injected with propranolol, and $n=10$ injected with vehicle) received their respective

155 injections at 07:30 (a total of 60 mice were used). Mice were weighed on an electronic scale (to 
156 the nearest $0.1 \mathrm{~g}$ ) every week to track changes in body mass in response to CSF. A schematic of

157 the overall experimental design is presented in Figure 1.

158

159 Sample Collection

160 In both experiments, $24.5 \mathrm{~h}$ following drug administration (08:00), mice were deeply

161 anesthetized using isoflurane vapors $(<2 \mathrm{~min})$ and rapidly decapitated in $<3 \mathrm{~min}$ of initial

162 handling for tissue gene expression studies and measurement of baseline serum corticosterone

163 concentration. Trunk blood from decapitated mice was collected, kept on ice for $<20 \mathrm{~min}$, and

164 then spun at $3000 \times \mathrm{g}$ for $30 \mathrm{~min}$ at $4^{\circ} \mathrm{C}$. The serum was collected and stored at $-20^{\circ} \mathrm{C}$ for later

165 ELISA analyses. For gene expression studies, the brain, extra-oviductal white adipose tissue

166 (EOWAT), heart, liver, and spleen were dissected from mice and stored in RNAlater solution

167 (ThermoFischer Scientific). Brain samples were later dissected and pre-frontal cortexes,

168 hippocampi, and hypothalami were collected, and placed in RNAlater. All tissue samples were

169 stored at $4^{\circ} \mathrm{C}$ for no more than 30 days before RNA extraction (see below).

170

171 ELISA

172

Serum levels of corticosterone ( $n=6-10$ /group) were measured as per the manufacturer's

173 protocols (Catalogue number: ADI-900-097, EnzoLife Sciences; Abcam). Average intra- and

174 inter-assay coefficients of variation were $4.6 \%$ and $7.2 \%$, respectfully.

175

176

Real time-PCR

177 The following protocols were described previously by Mishra et. al, 2020. Briefly, RNA

178 was extracted from EOWAT, heart, liver, spleen, and brain tissue using RNeasy mini kits 
179 (Qiagen). RNA concentrations were assessed with a NanoDrop 2000 Spectrophotometer

180 (ThermoScientific). Using a high-capacity cDNA reverse transcription kit (Life Technologies,

181 Cat number:1384368813, Total RNA was reverse transcribed into cDNA. The relative cytokine

182 gene expression was determined by using the prepared cDNA as a template and running samples 183 on a ABI 7300 RT-PCR system. Cytokine probes (IL1 $\beta$ : Mm00434228, TNF $\alpha$ : Mm00443258, 184 TGF $\beta$ : Mm00447500; Applied Biosystems) labelled with fluorescent marker 5-FAM at the 5' 185 end and quencher MGB at the 3'end was used for genes of interest. A primer-limited 18S probe 186 (4319413E; Applied Biosystems) was used as the endogenous control. Samples were run in 187 duplicate. Cycle threshold $(\mathrm{Ct})$ was used to calculate the relative expression in mRNA levels of 188 the genes of interest relative to the endogenous control using a standard curve. The relative 189 expression was then converted to fold change. A standard curve was created by injecting a 190 mouse with $100 \mu \mathrm{L}$ lipopolysaccharide $(1 \mathrm{mg} / \mathrm{kg} \mathrm{BW})$ to induce a severe pro-inflammatory 191 response, extracting RNA from the liver, and then reverse transcribing the RNA into cDNA. The 192 cDNA was used to create a ten-fold series dilution $(1: 1,1: 10,1: 100,1: 1000,1: 10000)$ to 193 generate the standard curve plot points. Outliers were removed based upon a two-sigma analysis. 194

Statistical Analyses

Data are presented as mean $( \pm \mathrm{SE})$. Statistical analyses were conducted in R Studio

197 (v.1.1.463, R Development Core Team, Boston, MA) and figures were visualized in GraphPad

198 Prisim 8 (Version 8.4.3 (686)). Animals and data points were excluded from the analysis if the

199 RealTime PCR or ELISA readings were undetermined. A two-way ANOVA assessed the effect 200 of sleep fragmentation (ASF and CSF), the effect of the adrenergic receptor blockers 201 (propranolol and phentolamine), and the interaction effect of ASF and CSF with the 
202 pharmacological blocker on cytokine mRNA expression and serum corticosterone concentration.

203 The interaction term was removed from the model if it was nonsignificant to preserve degrees of

204 freedom. Tukey's HSD test was used for post-hoc analysis. Logarithmic transformation was used

205 to satisfy the requirement of homogeneity of variances. A one-way repeated measures ANOVA

206 assessed the effect of CSF, time (the repeated measure), and their interaction effect upon body

207 mass. Tukey's HSD test was used for post-hoc analysis. Results are presented as means \pm 1 SE, 208 and $p<0.05$ was considered statistically significant.

209

\section{Results}

\section{Acute Sleep Fragmentation (ASF)}

212 Serum Corticosterone

213 ASF increased serum corticosterone (Cort) concentration $\left(F_{1,34}=5.66, p=0.003\right.$ Fig. 2 A)

214 while drug treatment had no effect on serum Cort $\left(F_{2,34}=2.78, p=0.08\right.$, Fig. 2A). An interaction

215 between drug and sleep treatments was present $\left(F_{2,34}=4.58, p=0.02\right.$, Fig. 2A); ASF Propranolol 216 (Pro) exhibited significantly elevated serum Cort relative to Control (CON) Vehicle (Veh) and 217 ASF Phentolamine (Phe) groups (Tukey’s HSD, $p<0.05$ ).

218

219 Brain Response

220

ASF significantly increased gene expression of $\operatorname{IL} 1 \beta\left(F_{1,48}=161.52, p<0.001\right.$, Fig. 3A)

and TGF $\beta\left(F_{1,52}=1620.92, p<0.001\right.$, Fig. $\left.3 \mathrm{G}\right)$, but did not affect the expression of TNF $\alpha$

$\left(F_{1,43}=0.68, p=0.41\right.$, Fig. 3D) compared to controls. There was no significant effect of drug

223 treatment upon expression of any of the cytokines (IL1 $\beta, F_{2,48}=2.02, p=0.14$, Fig. 3A; TNF $\alpha$,

$F_{2,43}=2.40, p=0.10$, Fig. 3D; TGF $\beta, F_{2,52}=0.97, p=0.39$, Fig. $\left.3 \mathrm{G}\right)$. 
ASF significantly increased cytokine gene expression in hippocampus (IL1 $\beta: F_{1,45}=55.29$,

226

227

228

229

230

231

232

233

234

235

236

237

238

239

240

241

242

243

244

245

246

247

$p<0.001$, Fig. 3B; TNF $\alpha: F_{1,46}=94.89, p<0.001$, Fig. 3E; TGF $\beta$ : $F_{1,49}=1055.80, p<0.001$, Fig. $\left.3 \mathrm{H}\right)$

compared to controls. There was a significant effect from drug treatment on TNF $\alpha$ expression

$\left(F_{2,48}=4.813, p=0.01\right.$, Fig. $\left.3 \mathrm{E}\right)$, but not on IL $1 \beta$ expression $\left(F_{2,45}=2.42, p=0.10\right.$, Fig. $\left.3 \mathrm{~A}\right)$ or TGF $\beta$

$\left(F_{2,49}=0.62, p=0.54\right.$, Fig. $\left.3 \mathrm{H}\right)$. Tukey's HSD showed that Pro increased TNF $\alpha$ expression levels

compared to Phe and Veh. There was an interaction effect between drug and sleep treatments for

IL1 $\beta$ expression $\left(F_{2,45}=5.39, p=0.007\right.$, Fig. 3B $)$ and TGF $\beta$ expression $\left(F_{2,45}=5.012, p=0.01\right.$, Fig.

$3 \mathrm{H}$ ); however, post-hoc tests revealed only a significant difference between sleep treatments for each gene.

In hypothalamus, ASF significantly increased cytokine gene expression (IL1 $\beta$ :

$F_{1,47}=275.75, p<0.001$, Fig. $3 \mathrm{C}$; TNF $\alpha: F_{1,45}=49.54, p<0.001$, Fig. $3 \mathrm{~F}$; TGF $\beta: F_{1,47}=1373.84$,

$p<0.001$, Fig. 3I). Drug treatment also had an effect on cytokine gene expression (IL1 $\beta$ :

$F_{2,47}=18.23, p<0.001$, Fig. $3 \mathrm{C}$; TNF $\alpha: F_{2,45}=6.83, p=0.002$, Fig. $3 \mathrm{~F}$; TGF $\beta: F_{2,47}=1373.84$,

$p<0.001$, Fig. 3I). Specifically, Pro and Phe decreased IL1 $\beta$ and TGF $\beta$ expression relative to Veh

while TNF $\alpha$ expression was reduced by just Phe. There was an interaction effect between drug and sleep treatments influencing IL1 $\beta$ expression $\left(F_{2,47}=0.97, p<0.001\right.$, Fig. $\left.3 C\right)$; post-hoc tests revealed that ASF groups had higher expression levels than CON treated groups and that CON

Veh had higher expression levels than CON Phe and Pro.

\section{Peripheral Response}

ASF significantly increased gene expression of $\operatorname{IL} 1 \beta\left(F_{1,45}=156.50, p<0.001\right.$, Fig. 4A),

$\operatorname{TNF} \alpha\left(F_{1,46}=24.5, p=23.14\right.$, Fig. $\left.4 \mathrm{E}\right)$, and TGF $\beta\left(F_{1,43}=1048.37, p<0.001\right.$, Fig. 4I $)$ compared to controls in EOWAT. Drug treatment significantly altered the expression of $\operatorname{IL} 1 \beta\left(F_{2,45}=6.31\right.$, 
$248 p=0.004$, Fig. $4 \mathrm{~A})$ and $\operatorname{TGF} \beta\left(F_{2,43}=4.83, p=0.01\right.$, Fig. $\left.4 \mathrm{I}\right)$ but not $\mathrm{TNF} \alpha\left(F_{2,46}=0.58, p=0.56\right.$, Fig.

249 4E) relative to Veh. Post-hoc Tukey's test revealed that Phe decreased IL1 $\beta$ expression when 250 compared to Pro whereas Pro increased TGF $\beta$ expression compared with Veh.

251 In cardiac tissue, ASF significantly increased gene expression of $\operatorname{IL} 1 \beta\left(F_{1,38}=12.70\right.$, $252 p=0.001$, Fig. 4B) and TGF $\beta\left(F_{1,48}=805.94, p<0.001\right.$, Fig. $\left.4 \mathrm{~J}\right)$ compared with controls, however, $253 \mathrm{TNF} \alpha\left(F_{1,45}=356.66, p<0.001\right.$, Fig. $\left.4 \mathrm{~F}\right)$ expression levels were significantly lower than that of the 254 controls. There was a drug effect on the expression of $\operatorname{IL} 1 \beta\left(F_{2,38}=8.42, p<0.001\right.$, Fig. 4B $)$ and $255 \operatorname{TGF} \beta\left(F_{2,48}=7.22, p=0.002\right.$, Fig. 4J). Post-hoc tests showed that Pro suppressed the expression 256 levels of IL1 $\beta$ and TGF $\beta$ relative to Veh. There was no effect of the pharmacological blockade 257 on the expression of TNF $\alpha\left(F_{2,43}=0.19, p=0.83\right.$, Fig. $\left.4 \mathrm{~F}\right)$. There was an interaction effect on IL $1 \beta$ 258 gene expression $\left(F_{2,38}=3.42, p=0.04\right.$, Fig. 4B); post-hoc tests revealed that ASF Pro had IL1 $\beta$ 259 expression levels equal to that of CON groups, and that ASF Pro expression was significantly 260 lower than ASF Veh, but not ASF Phe (Fig. 4B). ASF treatment significantly increased hepatic gene expression of each cytokine assessed 262 (IL1 $\beta$ : $F_{1,48}=212.25, p<0.001$, Fig. 4 C; TNF $\alpha: F_{1,42}=2153.85, p<0.001$, Fig. $4 \mathrm{G}$; TGF $\beta$ :

$263 F_{1,47}=947.400, p<0.001$, Fig. $\left.4 \mathrm{~K}\right)$ relative to controls. There was no significant drug effect on the 264 expression of TGF $\beta\left(F_{2,47}=2.78, p=0.07\right.$, Fig. $\left.4 \mathrm{~K}\right), \operatorname{IL} 1 \beta\left(F_{2,48}=0.32, p=0.73\right.$, Fig. $\left.4 \mathrm{C}\right)$, or TNF $\alpha$ $265\left(F_{2,42}=1.86, p=0.17\right.$, Fig. $\left.4 \mathrm{G}\right)$. In spleen, ASF increased cytokine gene expression (IL1 $\beta$ : $F_{1,46}=65.294, p<0.001$, Fig. 4D; TNF $\alpha: F_{1,44}=189.456, p<0.001$, Fig. $4 \mathrm{H}$; TGF $\beta: F_{1,45}=575.832, p<0.001$, Fig. $\left.4 \mathrm{~L}\right)$ compared with controls. Drug treatment significantly decreased the expression of $\mathrm{TNF} \alpha\left(F_{2,44}=5.648\right.$, $p=0.00656$, Fig. $4 \mathrm{H})$ and TGF $\beta\left(F_{2,45}=4.936, p<0.0115\right.$, Fig. $\left.4 \mathrm{~L}\right)$ with Pro and Phe, respectively, relative to Veh injection. The effect of drug treatment on IL1 $\beta$ expression was not statistically 
271 significant $\left(F_{2,46}=3.188, p=0.0505\right.$, Fig. 4D). Table 1 provides a summary of results for ASF

272 effects, drug effects, and interaction effects on cytokine gene expression in brain and peripheral

273 tissues.

274

275 Chronic Sleep Fragmentation (CSF)

276 Serum Corticosterone

277 CSF increased serum Cort concentration $\left(F_{1,53}=14.11, p<0.001\right.$, Fig. $\left.2 \mathrm{~B}\right)$ relative to 278 controls, while drug treatment also altered serum corticosterone concentrations $\left(F_{2,53}=8.20\right.$, $279 p<0.001$, Fig. 2B). The interaction effect between drug and sleep treatments also had a 280 significant effect on corticosterone $\left(F_{2,34}=4.58, p=0.02\right.$, Fig. $\left.2 \mathrm{~B}\right)$; post-hoc tests revealed that 281 corticosterone concentrations of CSF Pro was not significantly different from controls while CSF 282 Phe and CSF Veh had significantly higher circulating concentrations than the controls.

283

284 Brain Response

285 In prefrontal cortex, CSF significantly increased cytokine gene expression (IL1 $\beta$ :

$286 F_{1,44}=30.70, p<0.001$, Fig. 5A; TNF $\alpha: F_{1,49}=39.39, p<0.001$, Fig. $5 \mathrm{D}$; TGF $\beta: F_{1,44}=66.60$, $287 p<0.001$, Fig. 5G) relative to controls. There was also a significant effect of drug treatment on 288 cytokine gene expression (IL1 $\beta, F_{2,44}=30.70, p<0.001$, Fig. $5 \mathrm{~A}$; TNF $\alpha, F_{2,49}=7.34,=0.002$, Fig. $2895 \mathrm{D}$; TGF $\beta, F_{2,44}=18.05, p<0.001$, Fig. 5G). Furthermore, an interaction effect between sleep and 290 drug treatments altered cytokine gene expression (IL1 $\beta, F_{2,44}=3.51, p=0.04$, Fig. 5A; TNF $\alpha$, $291 F_{2,49}=4.41, p=0.02$, Fig. 5D; TGF $\beta, F_{2,44}=11.57, p<0.001$, Fig. 5G). Post-hoc tests showed that 292 Pro and Phe groups significantly decreased IL1 $\beta$ expression levels compared to Veh among CSF 
293 mice. In addition, CSF Phe treatment significantly decreased TNF $\alpha$ and TGF $\beta$ expression levels 294 relative to CSF Phe and CSF Veh mice.

295 CSF significantly increased the gene expression of each cytokine in the hippocampus 296 (IL1 $\beta: F_{1,47}=40.94, p<0.001$, Fig. 5B; TNFa: $F_{1,49}=56.79, p<0.001$, Fig. 5E; TGF $\beta: F_{1,42}=58.06$, $297 p<0.001$, Fig. 5H) compared with controls. Drug treatment had a significant effect on TNF $\alpha$ 298 expression $\left(F_{2,49}=13.97, p<0.001\right.$, Fig. $\left.5 \mathrm{E}\right)$, a trending effect on $\operatorname{TGF} \beta\left(F_{2,49}=0.62, p=0.54\right.$, Fig. $2995 \mathrm{H})$, and no effect on IL1 $\beta\left(F_{2,47}=0.33, p=0.72\right.$, Fig. 5B). Tukey's HSD showed Phe and Pro300 treated groups had lower TNF $\alpha$ expression levels than Veh, while there were no significant 301 differences in drug treatments for TGF $\beta$. There was an interaction effect between drug and sleep 302 treatments in TNF $\alpha$ expression $\left(F_{2,49}=9.00, p=0.005\right.$, Fig. $\left.5 \mathrm{E}\right)$; post-hoc tests revealed that TNF $\alpha$ 303 expression levels in CSF Phe were significantly less than CSF Pro and Veh, and not significantly 304 different from controls.

305 In hypothalamus, CSF had an effect on gene expression of $\operatorname{IL} 1 \beta\left(F_{1,50}=47.92, p<0.001\right.$, 306 Fig. 5C) and TNF $\alpha\left(F_{1,51}=11.74, p=0.001\right.$, Fig. 5F $)$ but not on TGF $\beta\left(F_{1,47}=0.21, p=0.65\right.$, Fig. 5I $)$ 307 relative to controls. Drug treatment, however, altered the gene expression of each cytokine 308 assessed (IL1 $\beta: F_{2,50}=22.04, p<0.001$, Fig. 5C; TNF $\alpha: F_{2,51}=16.38, p<0.001$, Fig. 5F; TGF $\beta$ : $309 F_{2,47}=1373.84, p<0.001$, Fig. 5I). Post-hoc tests showed Phe and Pro treated groups had higher 310 IL1 $\beta$ and TNF $\alpha$ expression levels than Veh, and that TGF $\beta$ was higher in Pro than in Phe or Veh. 311 There was an interaction effect between drug and sleep treatments influencing TNF $\alpha$ expression $312\left(F_{2,51}=3.75, p=0.03\right.$, Fig. $\left.5 \mathrm{~F}\right)$; however, post-hoc tests revealed that only CON Veh was 313 statistically different from all other treatment groups. 314

315 Peripheral Response 

expression of $\operatorname{IL} 1 \beta\left(F_{2,45}=6.31, p=0.004\right.$, Fig. $\left.6 \mathrm{~A}\right)$ and $\mathrm{TNF} \alpha\left(F_{2,49}=3.38, p=0.04\right.$, Fig. $\left.6 \mathrm{E}\right)$, but no effect upon TGF $\beta$. Post-hoc Tukey's revealed that Phe resulted in a lower IL1 $\beta$ and TNF $\alpha$ expression than when treated with Pro. A significant interaction effect in TGF $\beta$ expression $\left(F_{1,37}=10.00, p<0.001\right.$, Fig. 6I) was present, and post-hoc tests show CSF Phe had lower expression levels than CSF Pro, which was not significantly different from CON Phe.

$F_{1,42}=27.75, p<0.001$, Fig. $6 \mathrm{~B}$; TNF $\alpha: F_{1,41}=27.47, p<0.001$, Fig. $6 \mathrm{~F}$; TGF $\beta: F_{1,47}=92.81$, $p<0.001$, Fig. 6bJ) compared with controls. Drug treatment had a significant effect on the expression of each cytokine assessed (IL1 $\beta$ : $F_{2,45}=8.09, p=0.001$, Fig. $6 \mathrm{~B}$; TNF $\alpha$ : $F_{2,41}=12.21$, $p<0.001$, Fig. 6F; TGF $\beta$ : $F_{2,37}=7.49, p=0.002$, Fig. 6J). Post-hoc tests showed Phe and Pro reduced expression of IL1 $\beta$, and Phe reduced TNF $\alpha$ expression compared with Pro and Veh. There was an interaction between sleep and drug treatments on TGF $\beta$ expression $\left(F_{2,47}=8.16\right.$, $p<0.001$, Fig. 6J) and post-hoc tests indicate that CSF Veh and CSF Pro exhibited high TGF $\beta$ expression levels while CSF Phe had expression levels equal to CON Phe and Pro. $p=0.021$, Fig. $6 \mathrm{C})$ and $\operatorname{TGF} \beta\left(F_{1,49}=101.72, p<0.001\right.$, Fig. $\left.6 \mathrm{~K}\right)$, but not $\mathrm{TNF} \alpha\left(F_{1,44}=0.02\right.$, $p=0.89$, Fig. $6 \mathrm{G})$, relative to controls. There was no significant drug effect on the expression of 
TNF $\alpha: F_{1,38}=129.49, p<0.001$, Fig. $6 \mathrm{H}$; TGF $\beta: F_{1,45}=44.17, p<0.001$, Fig. $\left.6 \mathrm{~L}\right)$ compared with

340

341

342

343

344

345

346

347

348

349

350

351

352

353

354

355

356

357

358

359

360

controls. Drug treatment significantly altered the expression of $\operatorname{IL} 1 \beta\left(F_{2,39}=4.65, p=0.02\right.$, Fig.

$6 \mathrm{D})$ and TNF $\alpha\left(F_{2,38}=4.13, p=0.02\right.$, Fig. $\left.6 \mathrm{H}\right)$ but had no effect on TGF $\beta\left(F_{2,45}=1.45, p=0.25\right.$, Fig.

6L). Post-hoc test revealed that Pro reduced IL1 $\beta$ expression compared with Phe or Veh, and Phe reduced TNF $\alpha$ expression compared to Pro and Veh. There was an interaction effect between sleep treatment and drug treatment on TNF $\alpha$ expression $\left(F_{2,38}=5.73, p=0.007\right.$, Fig. $\left.6 \mathrm{H}\right)$, and posthoc tests revealed that expression levels in CSF Phe were significantly less than CSF Pro or Veh. Table 2 provides a summary of results for CSF effects, drug effects, and interaction effects on cytokine gene expression in brain and peripheral tissues.

\section{Body Mass}

There was an effect of sleep treatment $\left(F_{1,51.481}=52.32, p<0.001\right.$, Fig. 7$)$, time

$\left(F_{4,246.029}=4.47, p=0.02\right.$, Fig. 7$)$, and an interaction effect between CSF and time $\left(F_{4,246.029}=24.37\right.$, $p<0.001$, Fig. 7) on body mass. Post-hoc tests revealed that the percent change in body mass for control $(\mathrm{CON})$ and chronic sleep-fragmented (CSF) mice diverged at Week 2 and continued to do so at Week 3 and Week 4. Control mice gained body mass over time whereas CSF mice lost body mass (Fig. 7).

The raw data for this study have been provided as supplemental data files through Peer-J.

\section{Discussion}

Our results indicate that adrenergic receptor antagonists, phentolamine and propranolol, had varied effects upon the inflammatory phenotype, and that these effects were dependent upon 
361 acute versus chronic sleep fragmentation and tissue type. These results are consistent with a 362 previous study from our lab showing that chemical denervation of sympathetic nerve terminals 363 reduces inflammatory responses in peripheral tissues of female mice (Mishra et al. 2020). This 364 study also confirms findings from previous studies (Dumaine and Ashley 2015, Mishra et al. 365 2020) that acute and chronic SF lead to elevated pro-inflammatory gene expression in peripheral 366 and brain tissues. Additionally, it was observed that CSF was a more potent inducer of 367 inflammation than ASF, as also seen in previous research (Mullington et al., 2010, Mishra et al., 368 2020). However, in some tissues, opposing effects were observed where pharmacological 369 blockade actually increased pro-inflammatory gene expression (e.g., increased TNF $\alpha$ expression 370 in hippocampus from propranolol treatment in the ASF experiment, increased IL1 $\beta$ and TNF $\alpha$ in 371 hypothalamus from propranolol and phentolamine treatments in CSF experiment), which was 372 unexpected.

373 TGF $\beta$ is generally regarded as an anti-inflammatory cytokine (Marie et al., 1996; Sanjabi 374 et al., 2009; Zhou et al., 2012) and it is therefore possible that increased TGF $\beta$ expression in 375 response to SF is a homeostatic mechanism to inhibit the action of pro-inflammatory cytokines.

376 On the other hand, there are examples of pro-inflammatory effects from TGF $\beta$ (reviewed in 377 Morikawa, 2016; see also empirical study Yan et al., 2014). TGF $\beta$ has been shown to promote 378 the differentiation of T helper 17 cells in conjunction with IL-6, which stimulates inflammation 379 and amplifies autoimmune conditions (Korn et al., 2009). There is also a synergistic relationship 380 between TGF $\beta$ and IL-4 that encourages the development of T cells which produces cytokines IL-9 and IL-10. These IL-9 and IL-10 producing T cells promote tissue inflammation and do not 382 engage in suppressive activity (Zhou et al., 2008). Further research is needed to determine the 383 exact role that TGF $\beta$ plays in regulating SF-mediated immune responses. 
385

386

387

388

389

390

391

392

393

394

395

396

397

398

399

400

401

402

403

404

405

406

at decreasing pro-inflammatory gene expression in hypothalamus of ASF and control mice, while having no effect upon pre-frontal cortex or hippocampus. The same effect was observed in EOWAT with a reduction in IL1 $\beta$. In contrast, in the CSF experiment, the effect of phentolamine on cytokine gene expression was more widespread, and there was an increased occurance of interaction effects in comparison to the ASF Experiment. Among CSF mice, phentolamine decreased IL1 $\beta$ expression in prefrontal cortex and TNF $\alpha$ expression in hippocampus compared to vehicle. In addition, phentolamine reduced TNF $\alpha$ expression in spleen and decreased TGF $\beta$ expression in heart of CSF mice relative to vehicle. These findings suggest that mice experiencing CSF respond differently to an $\alpha$-adrenergic receptor blockade than mice only experiencing $24 \mathrm{~h}$ of SF. Previous research has shown that increased sympathetic tone induced by chronic stressors, including chronic sleep loss, diminishes $\alpha$-adrenergic receptor quantity and sensitivity in the brain and peripheral vasculature (Grote, 2000; Kim et al., 2013; Schmidt et al., 2019). In relation to the immune system, a number of immune cells are regulated by $\alpha$-adrenergic receptor stimulation including cell proliferation, cytokine production, lytic activity and antibody production (Grisanti, 2011). In this study, the effect of phentolamine on inflammatory responses could involve either changes in blood flow to various target tissues or direct interactions on immune cells, although further study is warranted.

We originally predicted that propranolol (non-selective $\beta$-adrenergic blocker) would have a greater effect upon inflammatory responses than phentolamine. However, this hypothesis was not clearly supported. For example, In the CSF experiment, phentolamine treated mice exhibited decreased mRNA expression of IL1 $\beta$, TNF $\alpha$, and TGF $\beta$ while propranolol only decreased IL1 $\beta$ expression. These data suggest that these tissues are sensitive to both $\alpha$ - and $\beta$-adrenergic 
407 receptor blockade, and catecholamines play a role in mediating inflammation in these tissues.

408 Our results support the hypothesis that catecholamines influence the distribution and activity of

$409 \beta$-adrenergic receptors in the brain due to chronic sleep loss (Radulacki and Micovic, 1982; Kim

410 et al., 2013). However, some tissues exhibited differential responses to propranolol, which

411 highlights the complexity of the effect that catecholamines have upon regulating inflammatory

412 responses. To help explain these disparate effects, it has been postulated that the net effect of

413 stimulating or inhibiting adrenergic receptors on immune cells is not straightforward, as there are

414 a variety of factors at play that can alter the outcome, such as the activation state of the target

415 cell, the proximity of the cell to the drug, and the pattern of expression of adrenergic receptors

416 (Pongratz and Straub, 2014). To control these variables, it would be ideal to examine the effects

417 of these adrenergic antagonists using cell lines or isolated cells derived from mice subjected to 418 SF.

419 Serum corticosterone concentration was elevated as a result of CSF and an interaction 420 effect of sleep and drug treatments showed that serum corticosterone in CSF mice receiving 421 propranolol was lower than other groups. In response to ASF and CSF, the hypothalamic422 pituitary-adrenal axis (HPA axis) was affected as evidenced by elevated serum corticosterone 423 (Cort) levels. The elevation in Cort is thought to act in an anti-inflammatory manner in response 424 to a stressor, e.g. sleep fragmentation, to suppress the action of pro-inflammatory cytokines 425 produced by the innate immune system (reviewed in Besedovsky and del Rey, 1996; but also see 426 Glover et al., 2009; Lima et al,. 2014; Mileya et al., 2017). As seen in previous experiments from 427 our lab, we show both acute and chronic sleep fragmentation resulted in elevated Cort levels 428 (Dumaine and Ashley 2018; Mishra et al., 2020). However, Cort concentration was lower in CSF 429 receiving vehicle than ASF receiving vehicle; another finding duplicated from our lab (Mishra et 
430 al., 2020). We report female mice subjected to ASF and given phentolamine exhibited a reduced

431 production of Cort, whereas treatment with propranolol reduced Cort concentrations in CSF

432 mice, suggesting that $\alpha$-adrenergic receptors are integral in regulating the HPA axis in ASF

433 conditions, while $\beta$-adrenergic receptors regulate the HPA axis in response to CSF. Both $\alpha$ - and

$434 \beta$-adrenergic receptors have been implicated in HPA axis regulation (Bugajski et al., 1995), and

435 the reduction of circulating Cort concentrations has been attributed to the down regulation of

436 SNS activity (Lowrance et al., 2016; Mishra et al., 2020). We suggest that reduction of Cort in

437 CSF mice receiving propranolol is the product of a combined effect of an adaptive neurologic

438 response to chronic stress, CSF, and the antagonistic action of the $\beta$-adrenergic receptor blocker,

439 propranolol. The abundance of hypothalamic $\beta$-adrenergic receptors decreases in response to

440 chronic stress (Stone and Platt, 1982; Thorsdottir et al., 2019), therefore increasing the efficacy

441 of propranolol and inhibiting catecholamine binding at the hypothalamus (Tuross and Patrick,

442 1986), which in turn reduces adrenocorticotropic hormone (ACTH) release (Spiga and Lightman,

443 2015) and consequently, Cort secretion.

444 In the past, there has been a general hesitancy of biomedical researchers to use female

445 mice because it was assumed that females are more variable than males and should be tested at

446 each stage of their 4-day estrous cycle. Because we did not assess the reproductive status of

447 female mice in our study, it cannot be ruled out that stage of estrous contributes to variation in

448 response. However, a meta-analysis revealed that randomly cycling female mice were no more

449 variable for a variety of physiological, behavioral, and molecular traits than male mice

450 (Prendergast et al., 2014), suggesting that estrous cycle plays a smaller role than originally

451 thought. Nevertheless, future studies should evaluate whether phasing of the estrous cycle affects

452 inflammatory responses to sleep loss in female mice. 
454 body mass from Week $2(0.65 \%)$ to Week $4(2.61 \%)$ while CSF decreased body mass from 455 Week $2(-2.41 \%)$ to Week $4(-6.53 \%)$. These findings are in contrast to male mice, where 8 456 weeks of CSF leads to body mass gain (Carreras et al., 2015). This sexual difference in body 457 mass regulation in response to CSF needs to be explored further.

\section{Conclusions}

To our knowledge, this is the first study assessing the effects of adrenergic receptor inflammatory responses appear to be representative of the activation of SNS and HPA and were correlated with SF duration. Additionally, there was a tissue-dependent response to phentolamine and propranolol, suggesting that both types of adrenergic receptors play a role in regulating inflammatory responses to SF (Tables 1 and 2). These results are also consistent with our previous findings from our lab and establishes that exposing mice to four weeks of CSF achieves comparable inflammatory effects seen in eight weeks of CSF (Mishra et al., 2020). Lastly, this study provides evidence that both $\alpha$ - and $\beta$-adrenergic receptors are involved in the SNS regulation of inflammatory responses to $\mathrm{SF}$, but their contribution likely differs relative to acute versus chronic SF. There were twice as many significant interactions between sleep

471 fragmentation and adrenergic function during CSF than ASF, and both adrengeric receptor types 472 were recruited due to the prolonged exposure to SF. Therefore, future directions for this body of 473 work should be aimed at identifying which isoform(s) of $\alpha$ - and $\beta$-adrenergic receptors are most 474 influential in regulating this pro-inflammatory phenotype. Lastly, results from the research 
475 suggest could aid in the development of therapeutics that specifically target $\alpha$ - and $\beta$-adrenergic

476 receptors to mitigate inflammation in patients with OSA or other sleep disorders.

477 There were no conflicts of interest that existed with this study.

478

479 Acknowledgements

480

We thank Naomi Rowland for assistance with RT-PCR, and undergraduate students

481

Abigail Price, Manzar Rzayeva, and Molly Jean Taylor for aiding in tissue collection.

482

483 References

484

485

486

487

488

489

490

491

492

493

494

Neuroscience Letters 615:55-59

Allison S, Chamberlain M, Miller J, Ferguson R, Gillett A, Bemand B, Saunders R. 1969.

Effects of propranolol on blood sugar, insulin and free fatty acids. Diabetologia 5: 339-342

\section{Antunes-Rodrigues J, Marubayashi U, Favaretto AL, Gutkowska J, McCann, SM. 1993.}

Essential role of hypothalamic muscarinic and alpha-adrenergic receptors in atrial natriuretic peptide release induced by blood volume expansion. Proceedings of the National Academy of Sciences of the United States of America 90(21), 10240-10244.

Ashley NT, Sams DW, Brown AC, Dumaine JE. 2016. Novel environment influences the effect of paradoxical sleep deprivation upon brain and peripheral cytokine gene expression.

495 
496 Ashley NT, Weil ZM, Nelson RJ. 2012. Inflammation: mechanism, costs, and natural variation.

497 Annual Review of Ecology, Evolution, and Systematics 43:385-406

498

499 Auer LM, Trummer UG, Johansson BB. 1981. Alpha-adrenoreceptor antagonists and pial

500 vessel diameter during hypercapnia and hemorrhagic hypotension in the cat. Stroke 12(6):847-

501851

502

503 Barnes MA, Carson MJ, Nair MG. 2015. Non-traditional cytokines: How catecholamines and 504 adipokines influence macrophages in immunity, metabolism and the central nervous system.

505 Cytokine 72(2):210-219

506

507 Besedovsky HO, del Rey A. 1996. Immune-neuro-endocrine interactions: facts and hypotheses.

508 Endocrine Reviews 17(1):64-102

509

510 Bugajski J, Gadek-Michalska A, Ołowska A, Borycz J, Głód R, Bugajski AJ. 1995.

511 Adrenergic regulation of the hypothalamic-pituitary-adrenal axis under basal and social stress

512 conditions. Journal of Physiology and Pharmacology: An Official Journal of the Polish

513 Physiological Society 46(3):297-312

514

515 Cain DW, Cidlowski JA. 2017. Immune regulation by glucocorticoids. Nature reviews.

516 Immunology 17(4):233-247

517 
518 Carreras A, Zhang SX, Peris E, Qiao Z, Wang Y, Almendros I, Gozal D. 2015. Effect of

519 resveratrol on visceral white adipose tissue inflammation and insulin sensitivity in a mouse 520 model of sleep apnea. International Journal of Obesity 39:418-423

521

522

Dumaine JE, Ashley NT. 2015. Acute sleep fragmentation induces tissue-specific changes in 523 cytokine gene expression and increases serum corticosterone concentration. American Journal of 524 Physiology-Regulatory, Integrative and Comparative Physiology 308(12):R1062-R1069

525

526

Dumaine JE, Ashley NT. 2018. Acute sleep fragmentation does not alter pro-inflammatory 527 cytokine gene expression in brain or peripheral tissues of leptin-deficient mice. PeerJ 6:e4423

528

529

Fabian H, Chemerinski E, Merlo A, Izquierdo J. 1973. Effect of propranolol on free fatty 530 acids of mice plasma during a passive avoidance test. Psychopharmacologia 30(4):369-374

531

532

533

Faraut B, Boudjeltia KZ, Vanhamme L, Kerkhofs M. 2012. Immune, inflammatory and cardiovascular consequences of sleep deprivation and recovery. Sleep Medicine Reviews 16:137149

535

536

Frey DJ, Fleshner M, and Wright KP. 2007. The effects of 40 hours of total sleep deprivation 537 on inflammatory markers in healthy young adults. Brain, Behavior, and Immunity 21:1050-1057 538 
539 Fuchs, BA, Albright JW, Albright JF. 1988. Beta-adrenergic receptors on murine

540 lymphocytes: density varies with cell maturity and lymphocyte subtype and is decreased after

541 antigen administration. Cellular immunology 114(2):231-245

542

543 Furman D, Campisi J, Verdin E, Carrera-Bastos P, Targ S, Franceschi C, Ferrucci L, 544 Gilroy GW, Fasano A, Miller GW, Miller AH, Mantovani A, Weyand CM, Barzilai N, 545 Goronzy JJ, Rando TA, Effros RB, Lucia A, Kleinstreuer N, Slavich, GM. 2019. Chronic 546 inflammation in the etiology of disease across the life span. Nature Medicine 25:1822-1832 547

Glover M, Cheng B, Fan R, Pruett S. 2009. The role of stress mediators in modulation of cytokine production by ethanol. Toxicology and Applied Pharmacology 239(1):98-105

550

551

Goyal M, Johnson J. 2017. Obstructive Sleep Apnea Diagnosis and Management. Missouri

552

Medicine 114(2):120-124

553

554

Grisanti LA, Perez DM, Porter JE. 2011. Modulation of immune cell function by $\alpha(1)$ 555 adrenergic receptor activation. Current Topics in Membranes 67:113-138

556

557 Grote L, Kraiczi H, Hedner J. 2000. Reduced alpha- and beta(2)-adrenergic vascular response 558 in patients with obstructive sleep apnea. American journal of respiratory and critical care 559 medicine 162(4):1480-1487

560 
561 Hall P, Smith S, Jack D, Kendall M. 1987. The influence of beta-adrenoceptor blockade on the

562 lipolytic response to exercise. Journal of Clinical Pharmacy Therapeutics 12(2):101-106

563

564 Hermansen K, Hyttel I. 1971. The hyperglycaemic activity of some catecholamines and the 565 effect of alpha- and beta-adrenergic blocking compounds in the mouse. Acta Pharmacologica 566 Toxicologica 29(1):87-94

567

568

Irwin MR, Opp MR. 2017. Sleep health: reciprocal regulation of sleep and innate immunity.

569

Neuropsychopharmacology: Official Publication of the American College of

570 Neuropsychopharmacology 42(1):129-155

571

572

Jun J, Shin M, Devera R, Yao Q, Mesarwi O, Bevans-Fonti S, Polotsky V. 2014. Intermittent

573 hypoxia-induced glucose intolerance is abolished by $\alpha$-adrenergic blockade or adrenal

574 medullectomy. American Journal of Physiology, Endocrinology, and Metabolism

575 307(11):E1073-E1083

576

577 Kim Y, Chen L, McCarley RW, Strecker RE. 2013. Sleep allostasis in chronic sleep

578 restriction: the role of the norepinephrine system. Brain Research 1531:9-16

579

580 Kolmus K, Tavernier J, Gerlo S. 2015. $\beta 2$-adrenergic receptors in immunity and inflammation:

581 stressing NF-кB. Brain, Behavior, and Immunity 45:297-310

582 
583 Korn T, Bettelli E, Oukka M, Kuchroo VK. 2009. IL-17 and Th17 Cells. Annual Review of

584 Immunology 27:485-517

585

586

Lima AA, Spínola LG, Baccan G, Correia K, Oliva M, Vasconcelos JF, Soares MB, Reis

587

SR, Medrado AP. 2014. Evaluation of corticosterone and IL1 $\beta$, IL-6, IL-10 and TNF- $\alpha$

588

expression after 670-nm laser photobiomodulation in rats. Lasers in Medical Science 29(2):709-

589 715

590

591

Limberger N, Fischer MR, Wichmann T, Starke K. 1989. Phentolamine blocks presynaptic

592

serotonin autoreceptors in rabbit and rat brain cortex. Naunyn-Schmiedeberg's Archives of

593

Pharmacology 340(1):52-61

594

595

Liu B, Hong JS. 2003. Role of microglia in inflammation-mediated neurodegenerative diseases:

596

mechanisms and strategies for therapeutic intervention. Journal of Pharmacology and

597

Experimental Therapeutics 304(1):1-7

598

599

Lowrance SA, Ionadi A, McKay E, Douglas X, Johnson JD. 2016. Sympathetic nervous

600 system contributes to enhanced corticosterone levels following chronic stress.

601

Psychoneuroendocrinology 68:163-170

602

603 Marie C, Pitton C, Fitting C, Cavaillon J. 1996. Regulation by anti-inflammatory cytokines

604 (IL-4, IL-10, IL-13, TGF $\beta$ ) of interleukin-8 production by LPS-and/or TNF $\alpha$-activated human 605 polymorphonuclear cells. Mediators of Inflammation 5(5):334-340 
606

607 Mavanji V, Billington CJ, Kotz CM, Teske JA. 2012. Sleep and obesity: a focus on animal 608 models. Neuroscience and Biobehavioral Reviews 36(3):1015-1029

609

610 Meerlo P, Sgoifo A, Suchecki D. 2008. Restricted and disrupted sleep: effects on autonomic 611 function, neuroendocrine stress systems and stress responsivity. Sleep Medicine Reviews 612 12(3):197-210

613

614 Mishra I, Pullum KB, Thayer DC, Plummer ER, Conkright BW, Morris AJ, O'Hara BF, 615 Demas GE, Ashley NT. 2020. Chemical sympathectomy reduces peripheral inflammatory 616 responses to acute and chronic sleep fragmentation. American Journal of Physiology.

617 Regulatory, Integrative and Comparative Physiology 318(4):R781-R789

618

619 Morikawa M, Derynck R, Miyazono K. 2016. TGF- $\beta$ and the TGF- $\beta$ Family: Context620 Dependent Roles in Cell and Tissue Physiology. Cold Spring Harbor Perspectives in Biology 621 8(5):a021873

622

623 Mullington JM, Simpson NS, Meier-Ewert HK, Haack M. 2010. Sleep loss and 624 inflammation. Clinical Endocrinology \& Metabolism 24(5):775-784

625

626 Peppard PE, Young T, Palta M, Dempsey J, Skatrud J. 2000. Longitudinal study of moderate 627 weight change and sleep-disordered breathing. Journal of the American Medical Association $628 \quad 284(23): 3015-3021$ 
629

630 Pongratz G, Straub RH. 2014. The sympathetic nervous response in inflammation. Arthritis

631 Research \& Therapy 16(6):504

632

633 Prendergast BJ, Onishi KG, Zucker I. 2014. Female mice liberated for inclusion in

634 neuroscience and biomedical research. Neuroscience Biobehavioral Reviews 40:1-5

635

636

Radulovacki M, Micovic N. 1982. Effects of REM sleep deprivation and desipramine on beta-

637 adrenergic binding sites in rat brain. Brain Research 235(2):393-396

638

639

Ramesh V, Kaushal N, Gozal D. 2009. Sleep fragmentation differentially modifies EEG delta

640 power during slow wave sleep in socially isolated and paired mice. Sleep Science, 2(2), 64-75.

641

642 Reid JL. 1986. Alpha-adrenergic receptors and blood pressure control. American Journal of

643 Cardiology 57(9):6E-12E

644

645 Richards, DA, Woodings EP, Prichard BN. 1978. Circulatory and alpha-adrenoceptor

646 blocking effects of phentolamine. British Journal of Clinical Pharmacology 5(6):507-513

647

648 Sanjabi S, Zenewicz LA, Kamanaka M, Flavell RA. 2009. Anti-inflammatory and pro-

649 inflammatory roles of TGF- $\beta$, IL-10, and IL-22 in immunity and autoimmunity. Current Opinion 650 in Pharmacology 9(4):447-453

651 
652 Schwartz S, McDowell Anderson W, Cole SR, Cornoni-Huntley J, Hays JC, Blazer D. 1999.

653 Insomnia and heart disease: a review of epidemiologic studies. Journal of Psychosomatic

654 Research 47(4):313-333

655

656 Spiga F, Lightman SL. 2015. Dynamics of adrenal glucocorticoid steroidogenesis in health and 657 disease. Molecular and Cellular Endocrinology 408:227-234

658

659 Straub RH, Schradin C. 2016. Chronic inflammatory systemic diseases: an evolutionary trade660 off between acutely benefical but chronically harmful programs. Evolution, Medicine, \& Public 661 Health 2016(1):37-51

662

663 Suchecki D, Lobo LL, Hipólide DC, Tufik S. 1998. Increased ACTH and corticosterone 664 secretion induced by different methods of paradoxical sleep deprivation. Journal of Sleep 665 Research 7(4):276-81

666

667 Stone EA, Platt JE. 1982. Brain adrenergic receptors and resistance to stress. Brain Research 668 237(2):405-414

669

670 Thorsdottir D, Cruickshank NC, Einwag Z, Hennig GW, Erdos B. 2019. BDNF

671 downregulates $\beta$-adrenergic receptor-mediated hypotensive mechanisms in the paraventricular 672 nucleus of the hypothalamus. American Journal of Physiology-Heart and Circulatory 673 Physiology 317(6):H1258-H1271 674 
675 Tiemeier H, Pelzer E, Jönck L, Möller HJ, Rao ML. 2002. Plasma catecholamines and

676 selective slow wave sleep deprivation. Neuropsychobiology 45(2):81-86

677

678 Tuross N, Patrick RL. 1986. Effects of propranolol on catecholamine synthesis and uptake in 679 the central nervous system of the rat. Journal of Pharmacology and Experimental Therapeutics $680 \quad$ 237(3):739-745

681

682 Wisor JP, Schmidt MA, Clegern WC. 2011. Evidence for neuroinflammatory and microglial 683 changes in the cerebral response to sleep loss. Sleep 34(3):261-272

684

685

Young T, Shahar E, Nieto FJ, Redline S, Newman AB, Gottlieb DJ, Walsleben JA, Finn L, 686

Enright P, Samet JM, Sleep Heart Health Study Research Group. 2002. Predictors of sleep687 disordered breathing in community-dwelling adults: the sleep heart health study. Archives of 688 Internal Medicine 162(8):893-900

689

690

Zhou L, Lopes JE, Chong MM, Ivanov II, Min R, Victora GD, Shen Y, Du J, Rubtsov YP, 691 Rudensky AY, Ziegler SF, Littman DR. 2008. TGF-beta-induced Foxp3 inhibits T(H)17 cell 692 differentiation by antagonizing RORgammat function. Nature 453(7192):236-240

693

Zhou X, Spittau B, Krieglstein K. 2012. TGF $\beta$ signaling plays an important role in IL4-

695 induced alternative activation of microglia. Journal of Neuroinflammation 9(1):210

696

697 Figure Legends 
698

699 Figure 1. Experimental Protocol for ASF and CSF Studies

700 Experimental protocol for the two experiments performed. Experimental mice subjected to sleep 701 fragmentation (SF) in an automated SF chamber for 24 hours (experiment 1: Acute SF) or 4

702 weeks (experiment 2: Chronic SF). An automated horizontally sweeping bar moved across the 703 bottom of the chamber every 2 minutes to ensure that sleep was regularly disrupted. The control 704 (CON) groups of each experiment were also contained in their own SF chambers, however, the 705 bars inside the chambers remained stationary. Mice were acclimated to the SF chambers for 72 706 hours (days 1-3) prior to the initiation of the experiments. In the Acute SF experiment (ASF), 707 control and experimental mice received an intraperitoneal injection of $0.9 \%$ saline (vehicle), 708 phentolamine, or propranolol 30 minutes before initiating their respective sleep treatments. After

70924 hours of ASF or CON treatment, mice (SF: $n=9 /$ group; CON: $n=10$ /group) were

710 decapitated for tissue gene expression quantification. In the Chronic SF (CSF) experiment, 711 control and experimental received an intraperitoneal injection of $0.9 \%$ saline (vehicle),

712 phentolamine, or propranolol 24 hours before the conclusion of the chronic sleep treatments.

713 After 4 weeks of CSF or CON sleep treatment, mice (SF: $n=10$ /group; CON: $n=10$ /group)

714 were decapitated for tissue gene expression quantification. All mice were $>8$ weeks of age, were 715 subjected to 12 hours light: 12 hours dark cycles with lights on at 8:00am and lights off at 716 8:00pm, and were provided food and water ad libitum.

717

718 Figure 2. ASF and CSF Experiments - Serum Corticosterone Concentration

719 Effects of acute sleep fragmentation (ASF, Fig. 4A) and chronic sleep fragmentation (CSF, Fig. 720 4B), adrenergic blockade (phentolamine (Phe) or propranolol (Pro)) or vehicle (Veh), and their 
721 interaction on serum corticosterone levels. Sample sizes of each treatment group are listed with

722 their respective bar graph and were analyzed using a two-way ANOVA and Tukey's HSD post

723 hoc tests. Data shown as means \pm 1 SE for each group and differing letters denotes $p<0.05$.

724

725 Figure 3. ASF Experiment - Cytokine mRNA Expression in Brain

726 Effects of acute sleep fragmentation (ASF), adrenergic blockade, and their interaction on

727 cytokine (IL1 $\beta, T N F \alpha$, and TGF $\beta$ ) mRNA expression in prefrontal cortex $(A, D, G)$,

728 hippocampus (B, E, H), and hypothalamus (C, F, I) of mice injected with a pharmacological

729 adrenergic block (phentolamine (Phe) or propranolol (Pro)) or vehicle (Veh) and were either

730 subjected to control (CON) or ASF. Sample sizes of each treatment group are listed with their

731 respective bar graph and were analyzed using a two-way ANOVA and Tukey's HSD post hoc

732 tests. Data shown as means $\pm 1 \mathrm{SE}$ for each group and differing letters denotes $p<0.05$.

733

734 Figure 4. ASF Experiment - Cytokine mRNA Expression in Peripheral Tissues

735 Effects of acute sleep fragmentation (ASF), adrenergic blockade, and their interaction on

736 cytokine (IL1 $\beta$, TNF $\alpha$, and TGF $\beta$ ) mRNA expression levels in EOWAT (A, E, I), heart (B, F,

$737 \mathrm{~J})$, liver (C, G, K), and spleen (D, H, L) of mice injected with a pharmacological adrenergic

738 block (phentolamine (Phe) or propranolol (Pro)) or vehicle (Veh) and were either subjected to

739 control (CON) or ASF. Sample sizes of each treatment group are listed with their respective bar

740 graph and were analyzed using a two-way ANOVA and Tukey's HSD post hoc tests. Data

741 shown as means \pm 1 SE for each group and differing letters denotes $\mathrm{p}<0.05$

742

743 Figure 5. CSF Experiment - Cytokine mRNA Expression in Brain 
744 Effects of chronic sleep fragmentation (CSF), adrenergic blockade, and their interaction on

745 cytokine (IL1 $\beta, T N F \alpha$, and TGF $\beta$ ) mRNA expression levels in prefrontal cortex (A, D, G),

746 hippocampus (B, E, H), and hypothalamus (C, F, I) of mice injected with a pharmacological

747 adrenergic block (Phentolamine (Phe) or Propranolol (Pro)) or vehicle (Veh) and were either

748 subjected to control (CON) or (CSF). Sample sizes of each treatment group are listed with their

749 respective bar graph and were analyzed using a two-way ANOVA and Tukey's HSD post hoc

750 tests. Data shown as means $\pm 1 \mathrm{SE}$ for each group and differing letters denotes $p<0.05$.

751

752 Figure 6. CSF Experiment - Cytokine mRNA Expression in Peripheral Tissues

753 Effects of chronic sleep fragmentation (CSF), adrenergic blockade, and their interaction on

754 cytokine (IL1 $\beta, T N F \alpha$, and TGF $\beta$ ) mRNA expression levels in EOWAT (A, E, I), heart (B, F,

$755 \mathrm{~J})$, liver (C, F, K), and spleen (D, H, L) of mice injected with a pharmacological adrenergic block

756 (phentolamine (Phe) or propranolol (Pro)) or vehicle (Veh) and were either subjected to control

757 (CON) or CSF. Sample sizes of each treatment group are listed with their respective bar graph

758 and were analyzed using a two-way ANOVA and Tukey's HSD post hoc tests. Data shown as

759 means $\pm 1 \mathrm{SE}$ for each group and differing letters denotes $p<0.05$.

760

761 Figure 7. CSF Experiment - Percentage Change in Body Mass

762 Effects of chronic sleep fragmentation (CSF) on weekly body mass. Timepoint "Week 0"

763 represents the start of the experiment. Sample sizes are CON n $=60$ and CSF $=60$, and were

764 analyzed using a repeated-measures ANOVA. Data are shown as means $\pm 1 \mathrm{SE}$ for each group

765 and asterisks $(*)$ denotes a significant difference between treatments at each timepoint, letters

766 denote differences within CON, and numbers denote difference within CSF $(p<0.05)$. 
768 Table 1. ASF Experiment - Summary of ASF effects, drug effects, and interaction effects on 769 cytokine gene expression in brain and peripheral tissues.

770

771 Table 2. CSF Experiment - Summary of CSF effects, drug effects, and interaction effects on 772 cytokine gene expression in brain and peripheral tissues.

773 


\section{Figure 1}

\section{Experimental Protocol for ASF and CSF Studies}

Experimental protocol for the two experiments performed. Experimental mice subjected to sleep fragmentation (SF) in an automated SF chamber for 24 hours (experiment 1: Acute SF) or 4 weeks (experiment 2: Chronic SF). An automated horizontally sweeping bar moved across the bottom of the chamber every 2 minutes to ensure that sleep was regularly disrupted. The control (CON) groups of each experiment were also contained in their own SF chambers, however, the bars inside the chambers remained stationary. Mice were acclimated to the SF chambers for 72 hours (days 1-3) prior to the initiation of the experiments. In the Acute SF experiment (ASF), control and experimental mice received an intraperitoneal injection of $0.9 \%$ saline (vehicle), phentolamine, or propranolol 30 minutes before initiating their respective sleep treatments. After 24 hours of ASF or CON treatment, mice (SF: $\mathrm{n}=$ 9/group; CON: $n=10 /$ group) were decapitated for tissue gene expression quantification. In the Chronic SF (CSF) experiment, control and experimental received an intraperitoneal injection of $0.9 \%$ saline (vehicle), phentolamine, or propranolol 24 hours before the conclusion of the chronic sleep treatments. After 4 weeks of CSF or CON sleep treatment, mice (SF: $n=10 /$ group; CON: $n=10 /$ group) were decapitated for tissue gene expression quantification. All mice were $>8$ weeks of age, were subjected to 12 hours light: 12 hours dark cycles with lights on at 8:00am and lights off at 8:00pm, and were provided food and water ad libitum 


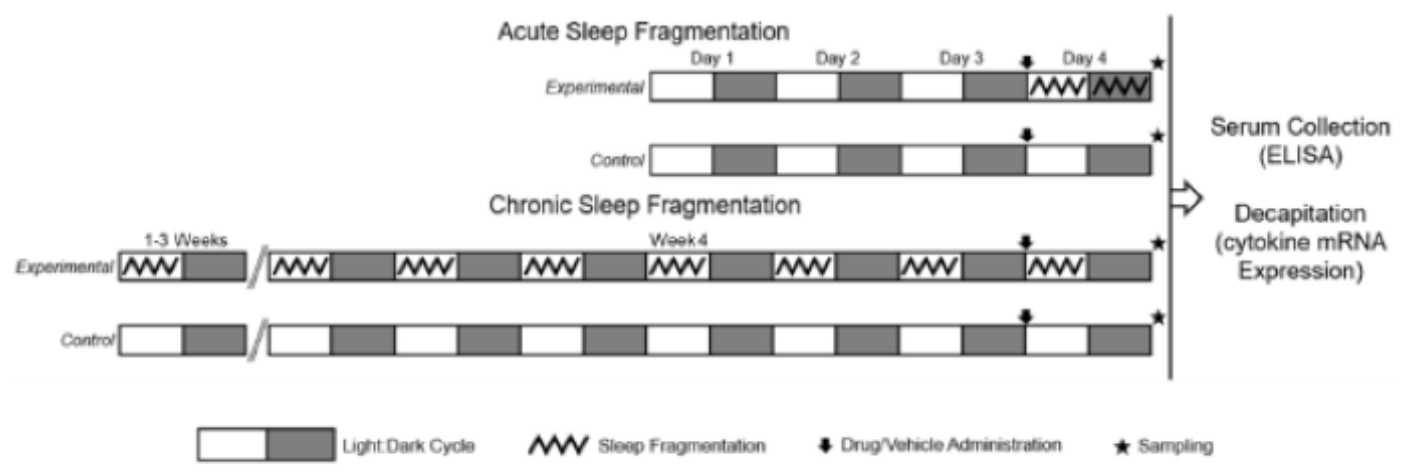




\section{Figure 2}

\section{ASF and CSF Experiments - Serum Corticosterone Concentration}

Effects of acute sleep fragmentation (ASF, Fig. 4A) and chronic sleep fragmentation (CSF, Fig. 4B), adrenergic blockade (phentolamine (Phe) or propranolol (Pro) or vehicle (Veh), and their interaction on serum corticosterone levels. Sample sizes of each treatment group are listed with their respective bar graph and were analyzed using a two-way ANOVA and Tukey's HSD post hoc tests. Data shown as means 1 SE for each group and differing letters denotes $p$ $<0.05$. 


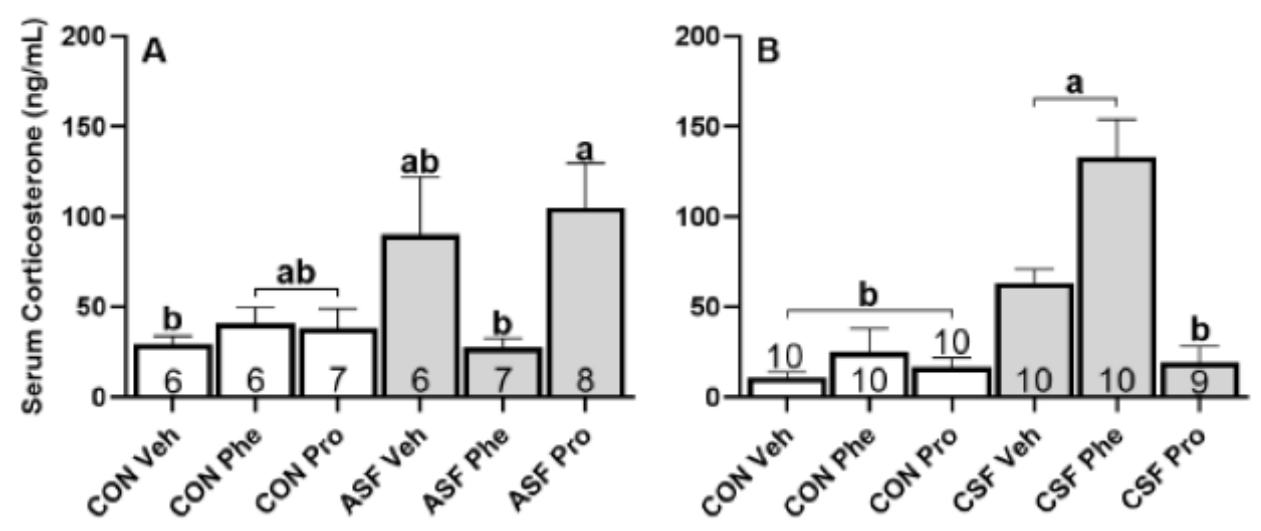




\section{Figure 3}

ASF Experiment - Cytokine mRNA Expression in Brain

Effects of acute sleep fragmentation (ASF), adrenergic blockade, and their interaction on cytokine (IL1 $\beta$, TNF $\alpha$, and TGF $\beta$ ) mRNA expression in prefrontal cortex (A, D, G), hippocampus $(B, E, H)$, and hypothalamus $(C, F, I)$ of mice injected with a pharmacological adrenergic block (phentolamine (Phe) or propranolol (Pro) or vehicle (Veh) and were either subjected to control (CON) or ASF. Sample sizes of each treatment group are listed with their respective bar graph and were analyzed using a two-way ANOVA and Tukey's HSD post hoc tests. Data shown as means 1 SE for each group and differing letters denotes $p<0.05$. 


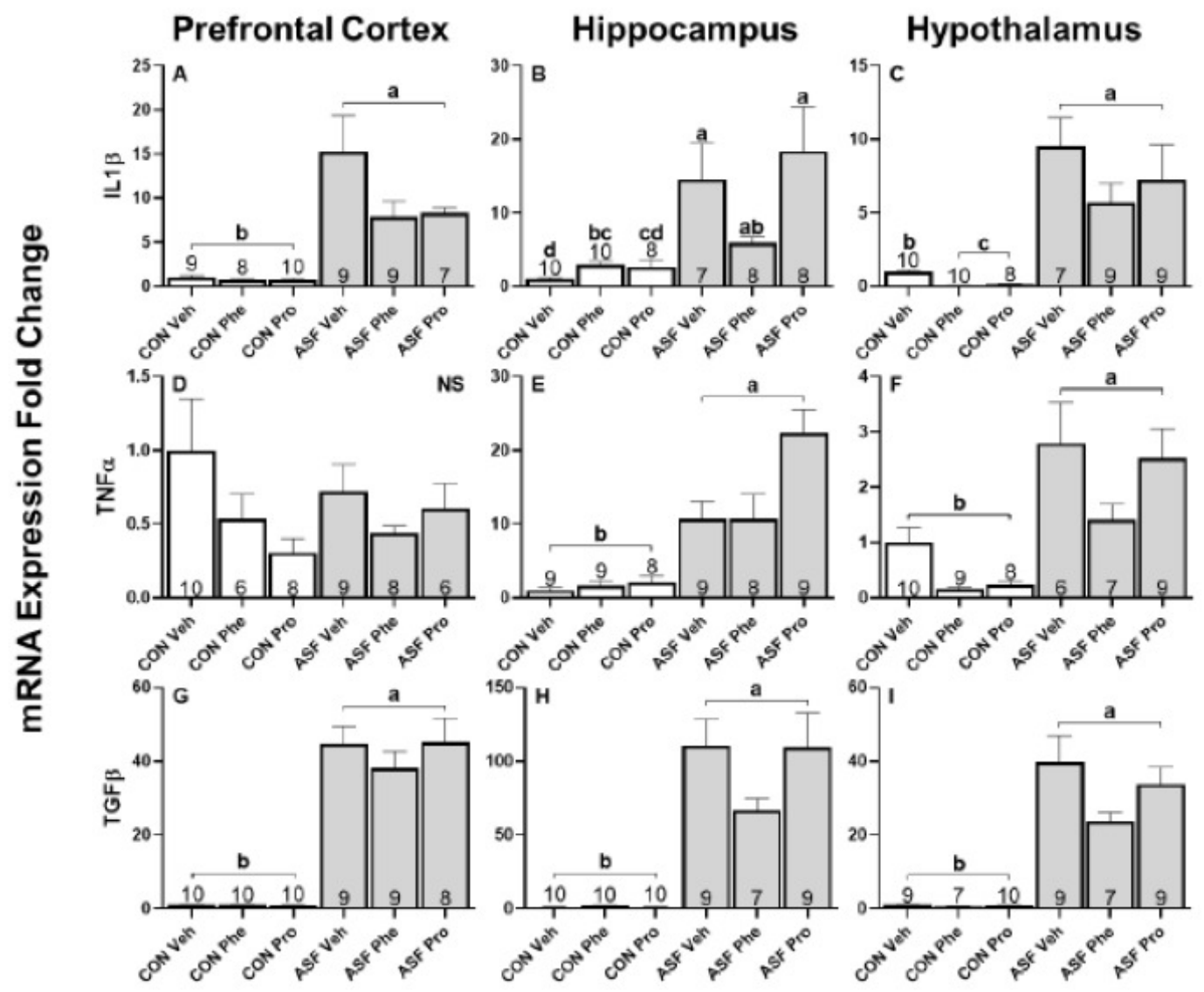




\section{Figure 4}

\section{ASF Experiment - Cytokine mRNA Expression in Peripheral Tissues}

Effects of acute sleep fragmentation (ASF), adrenergic blockade, and their interaction on cytokine (IL1 $\beta$, TNF $\alpha$, and TGF $\beta$ ) mRNA expression levels in EOWAT (A, E, I), heart (B, F, J), liver $(C, G, K)$, and spleen $(D, H, L)$ of mice injected with a pharmacological adrenergic block (phentolamine (Phe) or propranolol (Pro) or vehicle (Veh) and were either subjected to control (CON) or ASF. Sample sizes of each treatment group are listed with their respective bar graph and were analyzed using a two-way ANOVA and Tukey's HSD post hoc tests. Data shown as means 1 SE for each group and differing letters denotes $p<0.05$. 


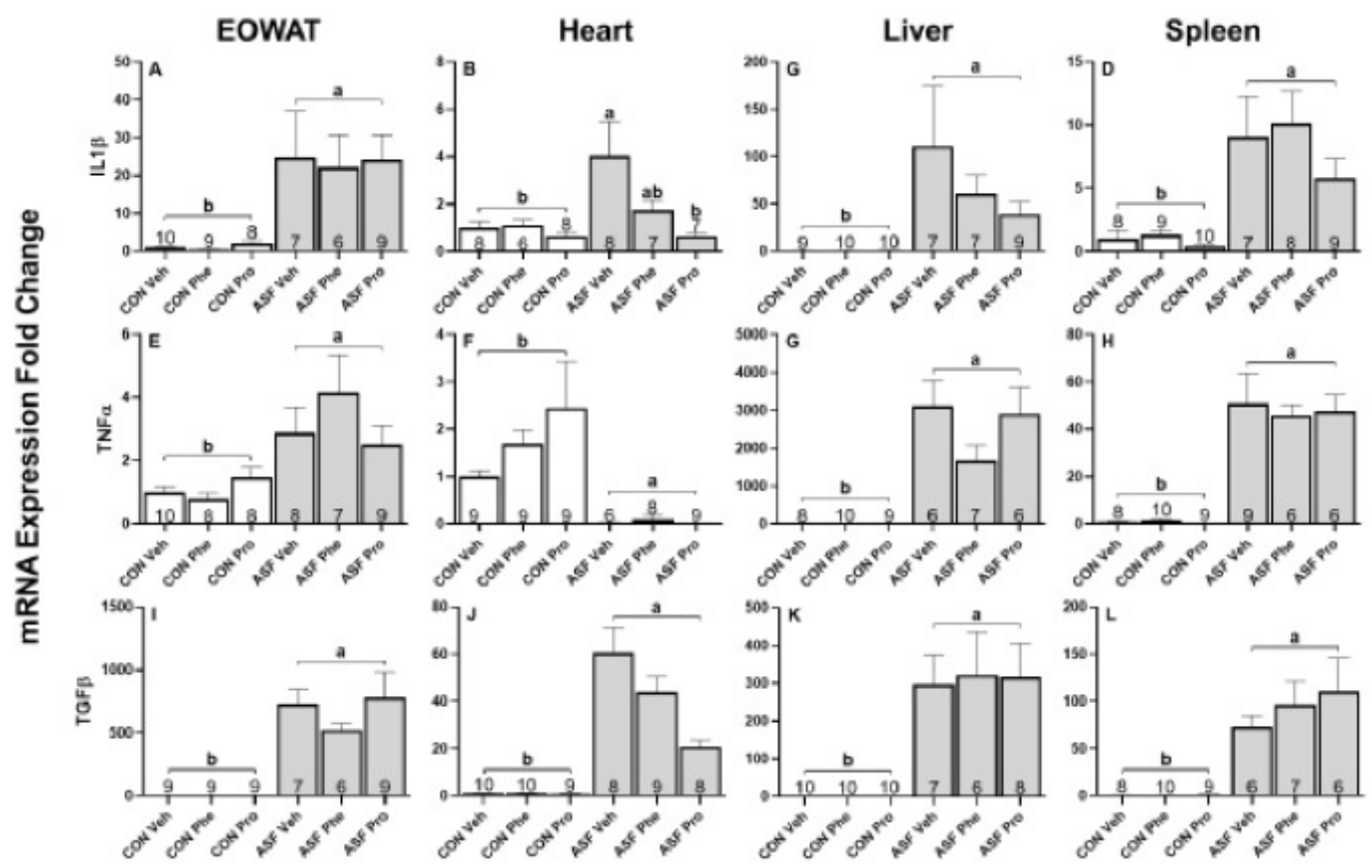




\section{Figure 5}

CSF Experiment - Cytokine mRNA Expression in Brain

Effects of chronic sleep fragmentation (CSF), adrenergic blockade, and their interaction on cytokine (IL1 $\beta$, TNF $\alpha$, and TGF $\beta$ ) mRNA expression levels in prefrontal cortex (A, D, G), hippocampus $(B, E, H)$, and hypothalamus $(C, F, I)$ of mice injected with a pharmacological adrenergic block (Phentolamine (Phe) or Propranolol (Pro) or vehicle (Veh) and were either subjected to control (CON) or (CSF). Sample sizes of each treatment group are listed with their respective bar graph and were analyzed using a two-way ANOVA and Tukey's HSD post hoc tests. Data shown as means $1 \mathrm{SE}$ for each group and differing letters denotes $p<0.05$ 


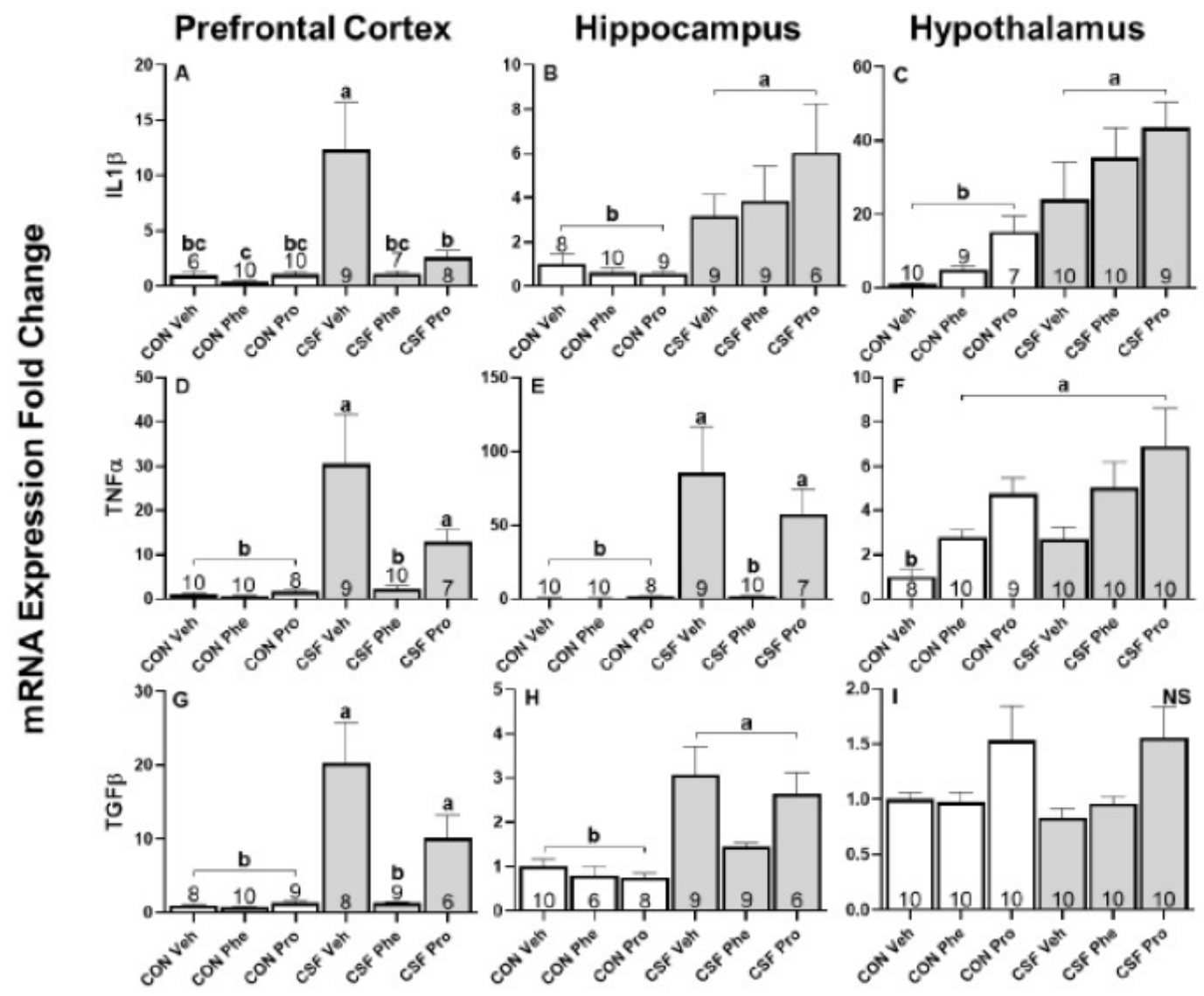




\section{Figure 6}

\section{CSF Experiment - Cytokine mRNA Expression in Peripheral Tissues}

Effects of chronic sleep fragmentation (CSF), adrenergic blockade, and their interaction on cytokine (IL1 $\beta$, TNF $\alpha$, and TGF $\beta$ ) mRNA expression levels in EOWAT (A, E, I), heart (B, F, J), liver $(C, F, K)$, and spleen $(D, H, L)$ of mice injected with a pharmacological adrenergic block (phentolamine (Phe) or propranolol (Pro) or vehicle (Veh) and were either subjected to control (CON) or CSF. Sample sizes of each treatment group are listed with their respective bar graph and were analyzed using a two-way ANOVA and Tukey's HSD post hoc tests. Data shown as means $1 \mathrm{SE}$ for each group and differing letters denotes $p<0.05$ 


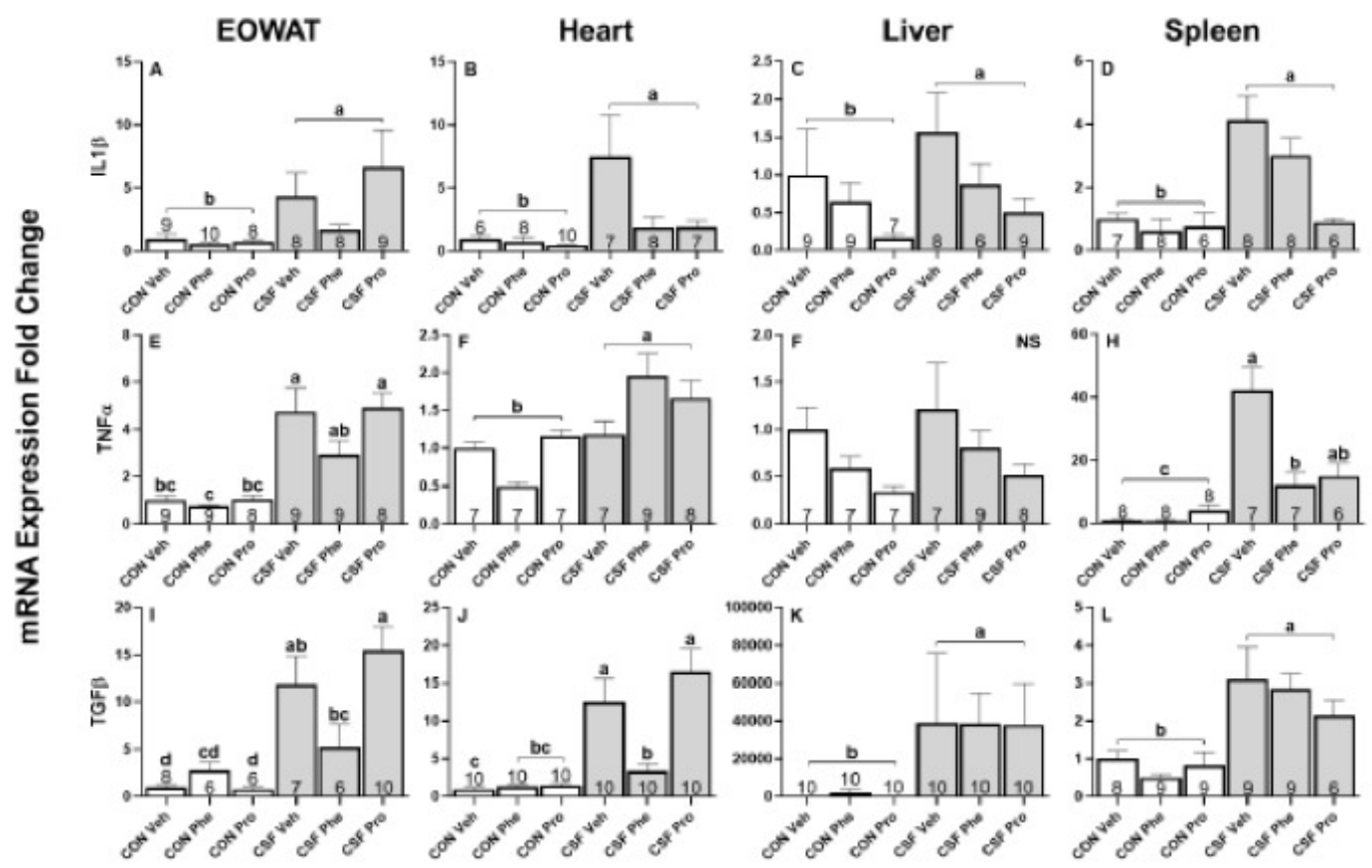




\section{Figure 7}

CSF Experiment - Percentage Change in Body Mass

Effects of chronic sleep fragmentation (CSF) on weekly body mass. Timepoint "Week 0" represents the start of the experiment. Sample sizes are CON $n=60$ and CSF $=60$, and were analyzed using a repeated-measures ANOVA. Data are shown as means 1 SE for each group and asterisks $\left.{ }^{*}\right)$ denotes a significant difference between treatments at each timepoint, letters denote differences within CON, and numbers denote difference within CSF $(p<0.05)$. 


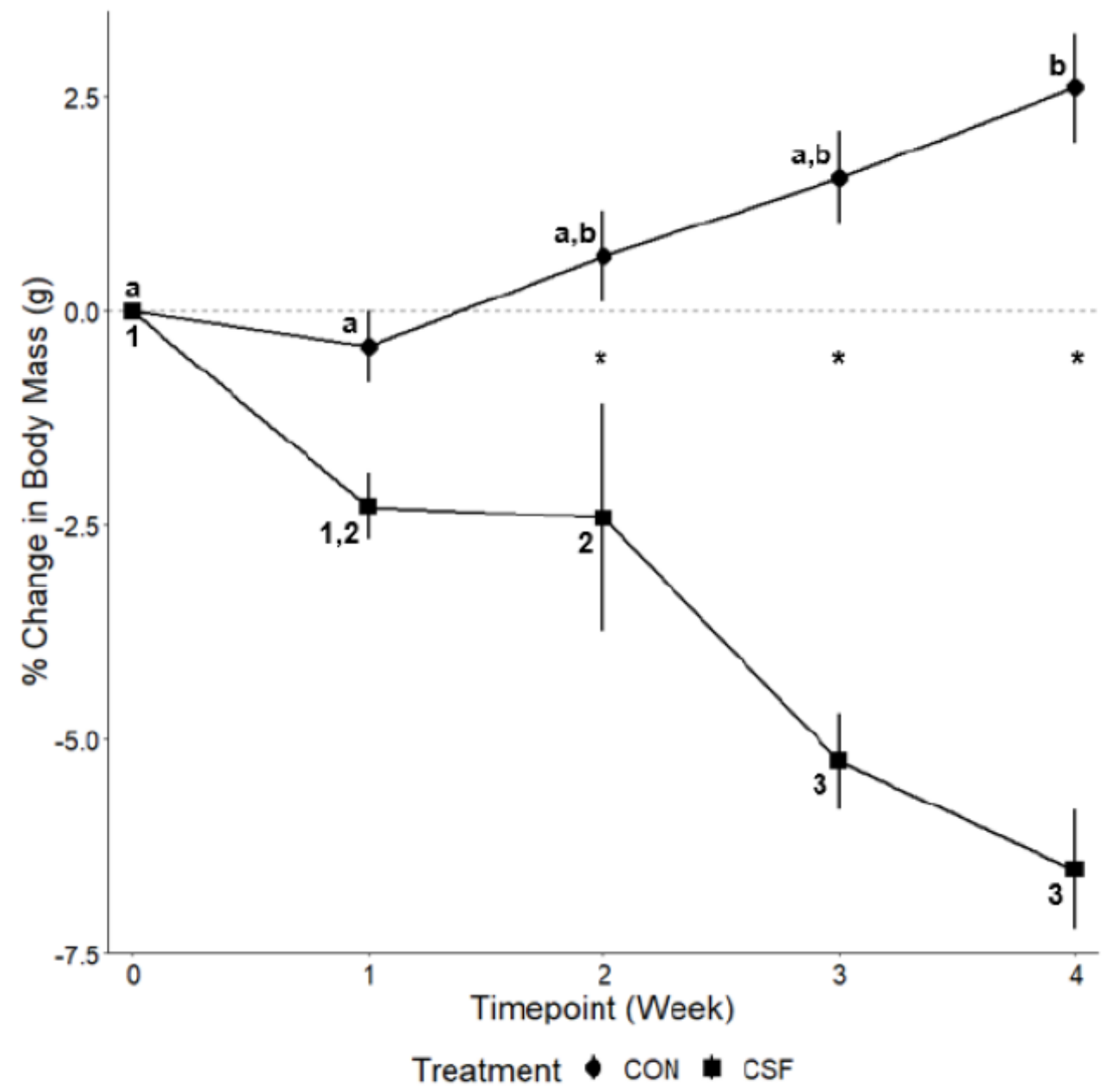




\section{Table 1 (on next page)}

Summary of ASF Results for Cytokine Gene Expression in Brain and Peripheral Tissues.

ASF Experiment - Summary of ASF effects, drug effects, and interaction effects on cytokine gene expression in brain and peripheral tissues 
Table 1. Summary of ASF Results for Cytokine Gene Expression in Brain and Peripheral Tissues.

\begin{tabular}{|c|c|c|c|c|}
\hline Tissue & Sleep Fragmentation & Phentolamine & Propranolol & Interaction \\
\hline Prefrontal Cortex & Increase: IL1 $\beta$ \& TGF $\beta$ & No Effect & No Effect & No Effect \\
\hline Hippocampus & $\begin{array}{c}\text { Increase: IL1 } \beta, \text { TNF } \alpha \\
\& \text { TGF } \beta\end{array}$ & No Effect & Increase: TNF $\alpha$ & No Effect \\
\hline Hypothalamus & $\begin{array}{c}\text { Increase: IL1 } \beta, \text { TNF } \alpha \text {, } \\
\text { \& TGF } \beta\end{array}$ & $\begin{array}{c}\text { Decrease: IL1 } \beta \text {, } \\
\text { TNF } \alpha, \& \text { TGF } \beta\end{array}$ & $\begin{array}{l}\text { Decrease: IL1 } \beta \\
\quad \& \text { TGF } \beta\end{array}$ & $\begin{array}{c}\text { Decrease: IL1 } \beta \\
\text { (CON Phe \& CON } \\
\text { Pro) }\end{array}$ \\
\hline EOWAT & $\begin{array}{c}\text { Increase: IL1 } \beta, \text { TNF } \alpha \\
\& \text { TGF } \beta\end{array}$ & Decrease: IL1 $\beta$ & Increase: TGF $\beta$ & No Effect \\
\hline Heart & $\begin{array}{c}\text { Increase: IL1 } \beta \text { \& TGF } \beta \\
\text { Decrease: TNF } \alpha\end{array}$ & No Effect & $\begin{array}{l}\text { Decrease: IL1 } \beta \\
\quad \& \text { TGF } \beta\end{array}$ & $\begin{array}{c}\text { Decrease: IL1 } \beta \\
\text { (ASF Pro) \& TGF } \beta \\
\text { (ASF Pro) }\end{array}$ \\
\hline Liver & $\begin{array}{c}\text { Increase: IL1 } \beta, \text { TNF } \alpha \\
\text { \& TGF } \beta\end{array}$ & No Effect & No Effect & No Effect \\
\hline Spleen & $\begin{array}{c}\text { Increase: IL1 } \beta, \text { TNF } \alpha \\
\& \text { TGF } \beta\end{array}$ & Decrease: TGF $\beta$ & Decrease: TNF $\alpha$ & No Effect \\
\hline
\end{tabular}




\section{Table 2 (on next page)}

Summary of CSF Results for Cytokine Gene Expression in Brain and Peripheral Tissues

CSF Experiment - Summary of CSF effects, drug effects, and interaction effects on cytokine gene expression in brain and peripheral tissues 
Table 2. Summary of CSF Results for Cytokine Gene Expression in Brain and Peripheral Tissues.

\begin{tabular}{|c|c|c|c|c|}
\hline Tissue & Sleep Fragmentation & Phentolamine & Propranolol & Interaction \\
\hline Prefrontal Cortex & $\begin{array}{c}\text { Increase: IL1 } \beta, \text { TNF } \alpha \text {, } \\
\text { \& TGF } \beta\end{array}$ & $\begin{array}{l}\text { Decrease: IL1 } \beta \text {, } \\
\text { TNF } \alpha, \& \text { TGF } \beta\end{array}$ & Decrease: IL1 $\beta$ & $\begin{array}{c}\text { Decrease: IL1 } \beta \\
\text { (CSF Phe \& Pro), } \\
\text { TNF } \alpha \text { (CSF Pro), } \\
\& \text { TGF } \beta \text { (CSF Phe) }\end{array}$ \\
\hline Hippocampus & $\begin{array}{c}\text { Increase: IL1 } \beta, \text { TNF } \alpha \\
\& \text { TGF } \beta\end{array}$ & No Effect & Decrease: TNF $\alpha$ & $\begin{array}{l}\text { Decrease: TNF } \alpha \\
\text { (CSF Phe) }\end{array}$ \\
\hline Hypothalamus & Increase: IL1 $\beta$ \& TNF $\alpha$ & $\begin{array}{c}\text { Increase: IL1 } \beta \text { \& } \\
\text { TNF } \alpha\end{array}$ & $\begin{array}{l}\text { Increase: IL1 } \beta \text {, } \\
\text { TNF } \alpha, \& \text { TGF } \beta\end{array}$ & No Effect \\
\hline EOWAT & $\begin{array}{c}\text { Increase: IL1 } \beta, \text { TNF } \alpha \\
\& \text { TGF } \beta\end{array}$ & $\begin{array}{c}\text { Decrease: IL1 } \beta \text { \& } \\
\text { TNF } \alpha\end{array}$ & No Effect & $\begin{array}{l}\text { Decrease: TGF } \beta \\
\text { (CSF Phe) }\end{array}$ \\
\hline Heart & $\begin{array}{c}\text { Increase: IL1 } \beta, \text { TNF } \alpha \\
\& \text { TGF } \beta\end{array}$ & $\begin{array}{l}\text { Decrease: IL1 } \beta \text {, } \\
\text { TNF } \alpha, \& \text { TGF } \beta\end{array}$ & Decrease: IL1 $\beta$ & $\begin{array}{l}\text { Decrease: TGF } \beta \\
\text { (CSF Phe) }\end{array}$ \\
\hline Liver & $\begin{array}{c}\text { Increase: IL1 } \beta, \text { TNF } \alpha \\
\& \text { TGF } \beta\end{array}$ & No Effect & No Effect & No Effect \\
\hline Spleen & $\begin{array}{c}\text { Increase: IL1 } \beta, \text { TNF } \alpha \\
\& \text { TGF } \beta\end{array}$ & Decrease: TNF $\alpha$ & Decrease: IL1 $\beta$ & $\begin{array}{l}\text { Decrease: TNF } \alpha \\
\text { (CSF Phe) }\end{array}$ \\
\hline
\end{tabular}

1 